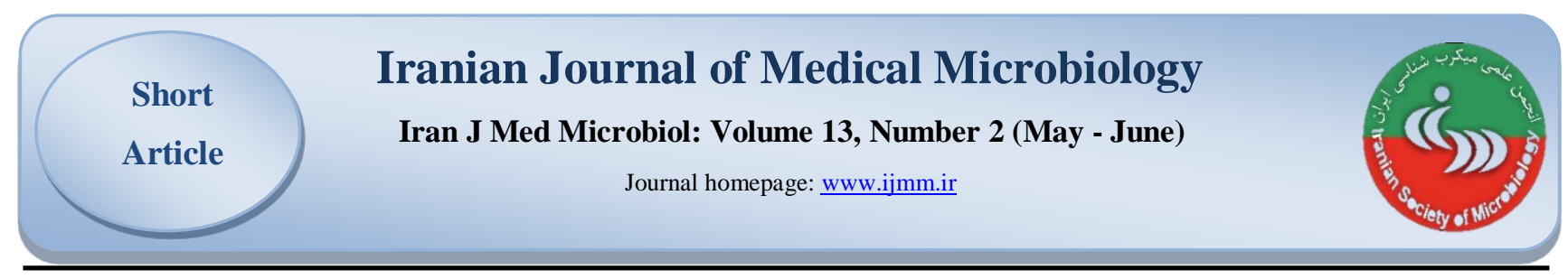

\title{
Antibacterial Properties of Ozonated Sunflower (Helianthus Annuus 1.) and Sesame (Sesamum Indicum L.) Oils on Staphylococcus Aureus
}

\author{
Sepideh Yousefi ${ }^{1}$, Mahmoud Pooryousef Miandoab ${ }^{2 *}$, Shahram Armeideh ${ }^{3}$
}

1. Department of Biology, Faculty of Basic Sciences, Urmia Branch, Islamic Azad University, Urmia, Iran

2. Department of Agronomy and Agro-Ecology, Faculty of Basic Sciences, Urmia Branch, Islamic Azad University, Urmia, Iran

3. Department of Plant Protection, Faculty of Agriculture, Urmia University, Urmia, Iran

\section{Article Information}

\section{Article Subject: \\ Antibiotic Resistance}

DOI:

\section{Corresponding author:}

\section{Mahmoud Pooryousef}

Miandoab,

Department of Agronomy and Agro-Ecology, Faculty of Basic Sciences, Urmia Branch, Islamic Azad University, Urmia, Iran

Email:

Pooryousefm@yahoo.com

Use your device to scan and read the article online

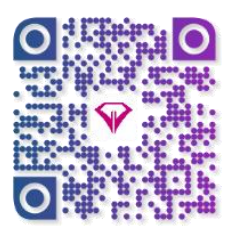

\section{Abstract}

Background and Aims: Staphylococcus aureus infection needs long-term treatment with antibiotics which may cause adverse effects on many body organs and antibiotics resistance. Therefore, the use of natural and herbal compounds has been under consideration.

Materials and Methods: In the present study, the effects of sunflower (Helianthus annuus) and sesame (Sesamum indicum) oils were assessed on S. aureus growth regarding zone of inhibited growth (Antibiogram test), Minimum Inhibitory Concentration (MIC) and Minimum Bactericidal Concentration (MBC).

Results \& Discussion: considering antibiogram test, there was a statistically significant difference between sesame and sunflower oil (72 hours ozonate) and pure sesame and sunflower oils and ciprofloxacin antibiotic, as well as negative control distilled water after 24 and 48 hours $(P \leq 0.05)$. The results showed that antibiotic, ozonated water, ozonated sesame and sunflower oils had 12,8, 4, and $3 \mathrm{~mm}$ inhibition zones after 24 hours on $S$. aureus bacteria, respectively. The MBC and MIC values of ozonated sunflower and sesame oil on $S$. aureus were $0.064,0.032,0.322$ and 0.008 $\mathrm{mg} / \mathrm{mL}$, respectively.

Sesame and sunflower oils can be used as inhibitors of the growth of $S$. aureus in pharmaceutical formulations such as wound and burn healing ointments.

Keywords: Ozonated sunflower oil, Ozonated sesame oil, Staphylococcus aureus, Antibiogram test

Received: 2018/11/03 Accepted: 2019/07/08 Available online: 2019/08/23

Copyright $\odot$ 2019. This is an open-access article distributed under the terms of the Creative Commons Attribution- 4.0 International License which permits Share, copy and redistribution of the material in any medium or format or adapt, remix, transform, and build upon the material for any purpose, even commercially.

How to cite this article:

Yousefi S, Pooryousef Miandoab M, Aramideh S. Antibacterial Properties of Ozonated Sunflower (Helianthus Annuus 1.) and Sesame (Sesamum Indicum L.) Oils on Staphylococcus Aureus. Iran J Med Microbiol. 2019; 13 (2) :132-136 


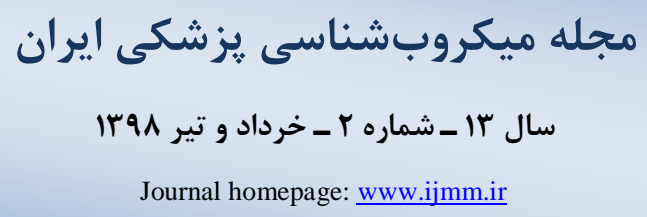

\title{
خواص ضدباكتريايى روغنهاى آنتابكردان (Helianthus annuus L) و كنجد (Sesamum indicum L)
} ازونهشده روى باكترى /ستافيلوكوكوس اورئوس در شرايط آزمايشكاهى

\author{
سييده يوسفى'، محمود يوريوسف مياندو آبّ"، شهرام آرميده
}

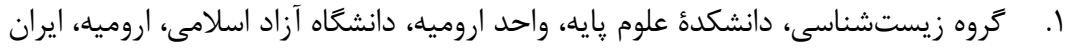

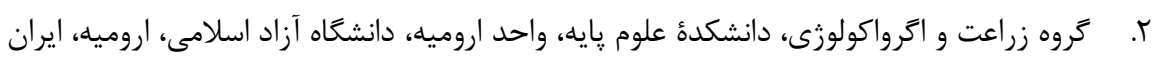

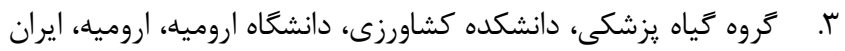

\section{جكسيل}

زمينه و هدف: با توجه به بيمارىزايى باكترى /ستافيلوكوكوس /ورئوس (Staphylococcus aureus) و درمان طولانى

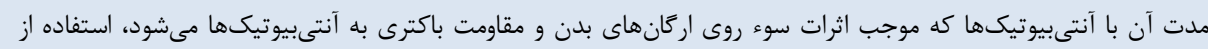
تركيبات طبيعى و كياهى مورد توجه است. مواد و روشكار: در مطالعه حاضر اثرات روغنهاى آفتابكردان(Helianthus annuus) و كنجد) مونه (Sesamum indicum)

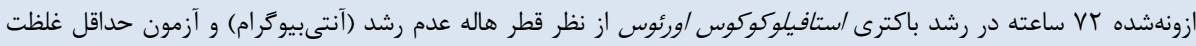

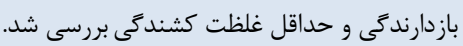

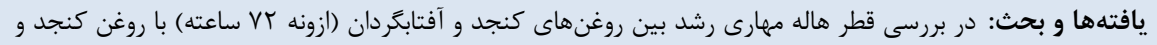

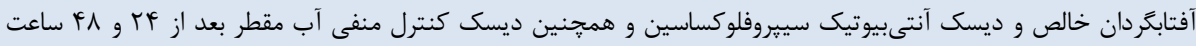

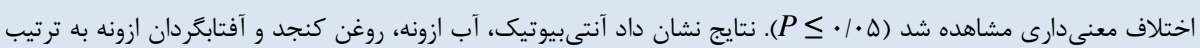

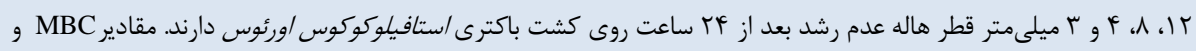

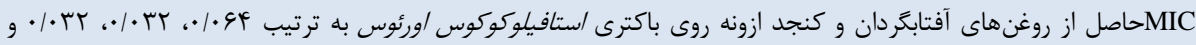

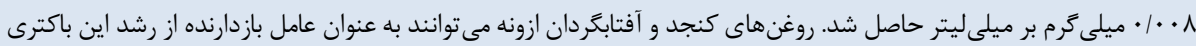
در فرمولاسيونهاى دارويى نظير يماد ترميم زخم و سوختخى مورد استفاده قرار كيرند.

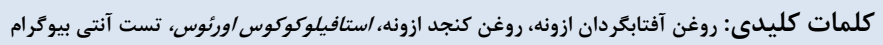

كيىرايت () مجله ميكروبشناسى بزشكى ايران: دسترسى آزاد؛ كيى بردارى، توزيع و نشر براى استفاده غيرتجارى با ذكر منبع آزاد است.
}

اطلاعات مقاله

تاريخهُ

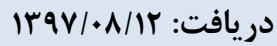

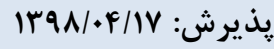

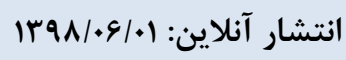

موضوع:

مقاومت يادزيستى (آنتى بيوتيكى)

IJMM1398;13(2): 132-136

نويسندهُ مسئول:

محمود يوريوسف مياندوآب

كروه زراعت و اكرواكولوزى، دانشكدة علوم

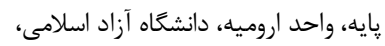

اروميه، ايران إندان إومانه

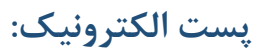

Pooryousefm@yahoo.com

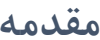

بيمارىزايى استافيلوكوكها مىتواند از طريق توانايى تكثير و انتشار كسترده در بافتهاى بدن و همين طور از طريق توليد تعداد زيادى مواد خارج سلولى باشد. بعضى از اين مواد آنزيم و تعدادى ديگر توكسين هستند (ץ). در درمان زخمهاى عفونى بيشتر از آنتىبيوتيكها استفاده ميىشود، به دليل مقاومت دهن آنتىبيوتيكها و با توجه عوارض جانبى و آسيبهاى زيادى كه بر

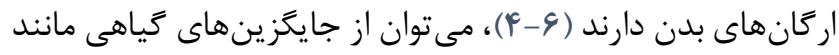
روغنها، عصارهها، يودرها، يمادها و عوامل فيزيكى مانند اشعهها

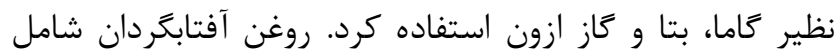
جربى هاى غير اشباع يگانه و جند
باكترى /ستافيلوكوكوس اورئوس ازگونههاى بيمارىزاى گرم

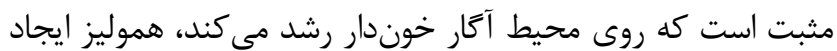
مى كند. اين باكترى ممكن است به شكل فلور عادى يوست يا بينى وجود داشته باشد و در ايجاد عفونت، از عفونتهاى ساده يوستى مانند جوشدانه، كورك، كفَيرك، كلمزه و آبسه كرفته تا بيمارىهاى تهديدكننده زندگى مانند ينومونى، مننزيت، استئوميليت، اندو كارديت، سندرم شوكسمى و سيتىسمى نقش دارد. /ستافيلوكوك /ورئوس به عنوان يكى از زنج عامل شايع ايجادكننده عفونتهاى بيمارستانى به

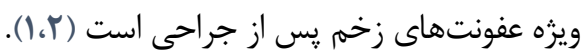




\section{نحوه آزمايش انتشار ديسك}

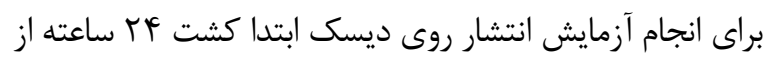

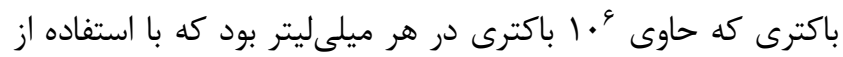

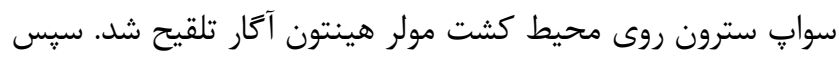

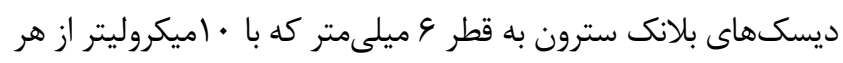

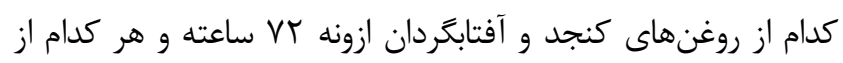

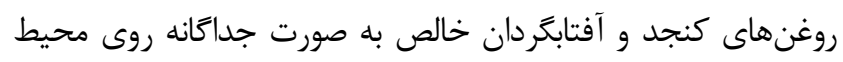

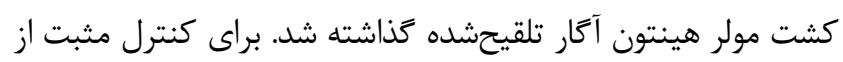

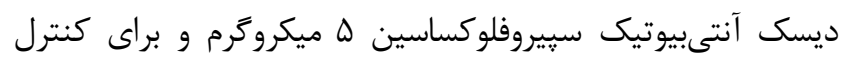

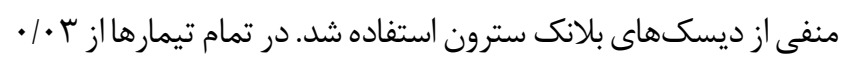
درصد دى متيل سولفوكسايد Dimethyl sulfoxide

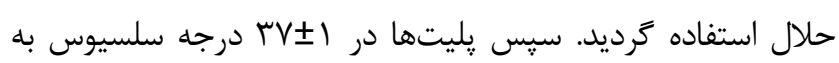

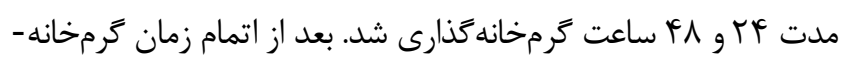

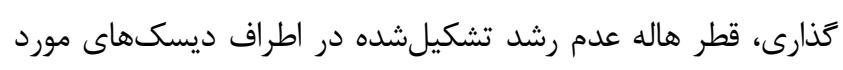

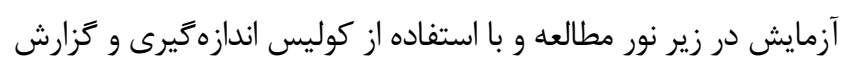

شد (1) (1).

آزمايش تعيين حداقل غلظت بازدارندكى (1) (MIC) و حداقل

غلظت كشندىى (MBC)

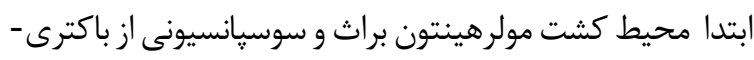

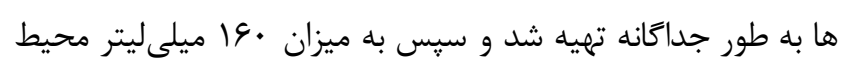

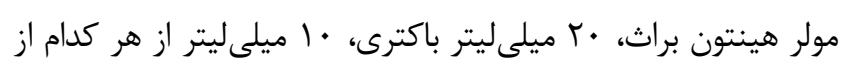

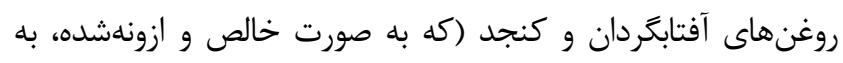

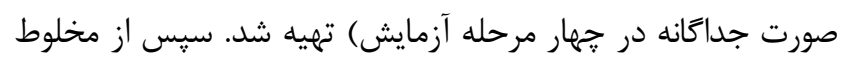

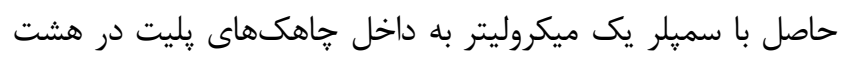

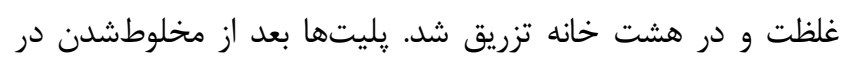

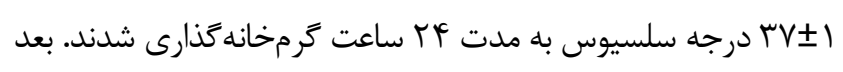

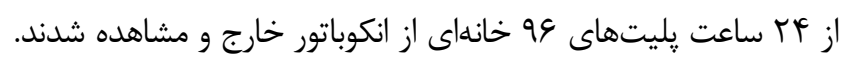

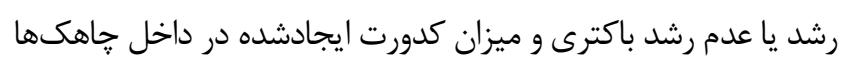

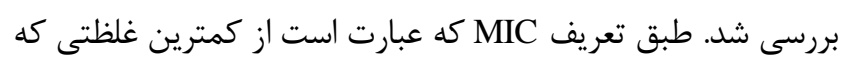

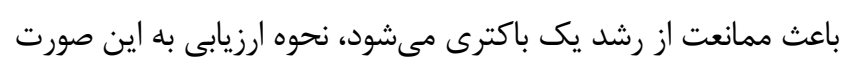

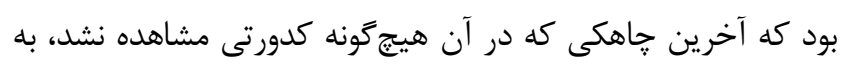
عنوان MIC در نظر كرفته شد. به منظور تعيين MBC مواد دان داخل هر

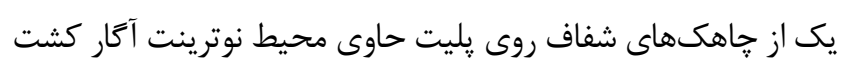

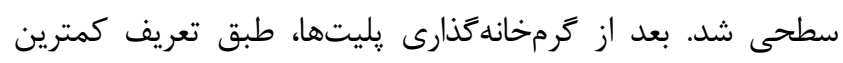

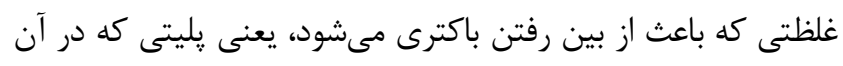

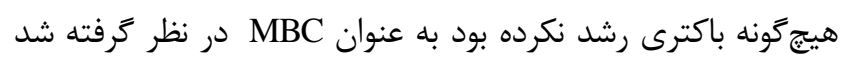

است كه به خاطر كاهش خطر مشكلات قلبى و خواص ضدالتهابى

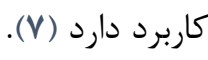

خواص آنتىاكسيدانى فوقالعاده در روغن كنجد به دليل

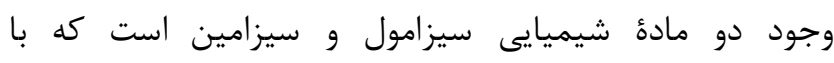

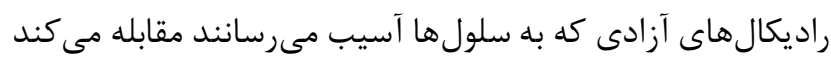

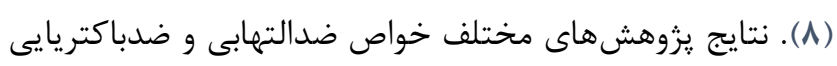

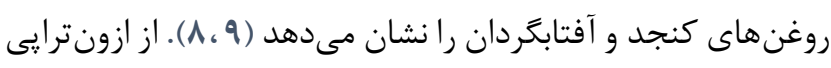

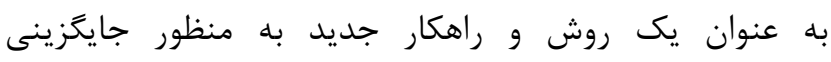

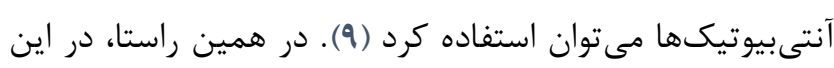

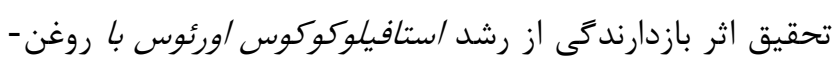

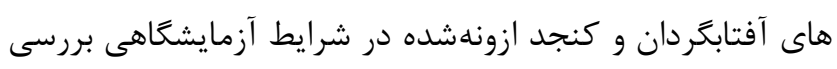
شد.

\section{مواد و روش ها}

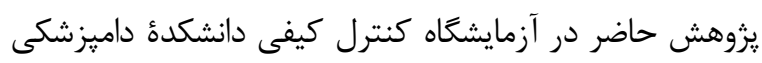

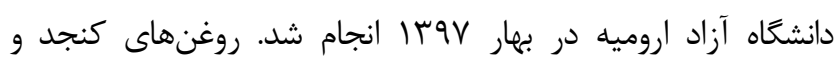

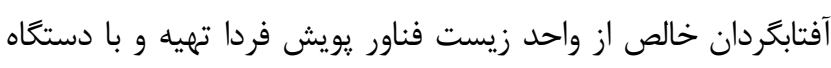

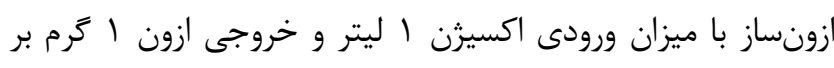

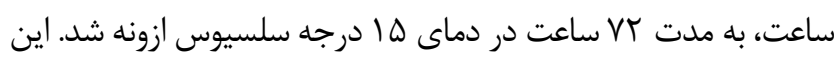

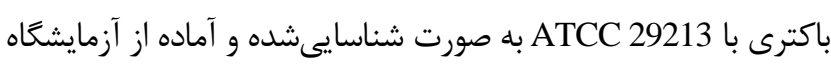

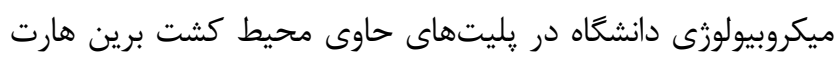

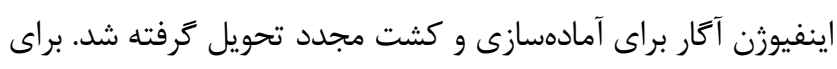

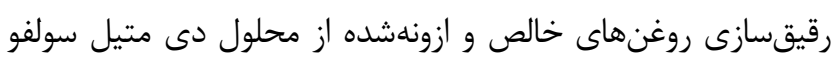

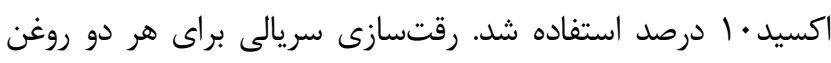

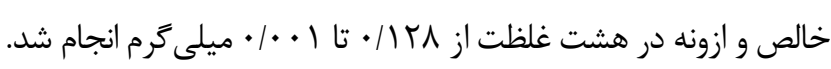

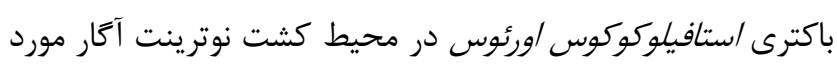

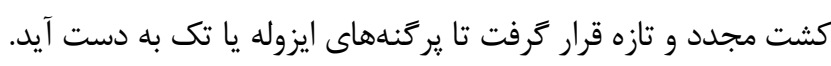

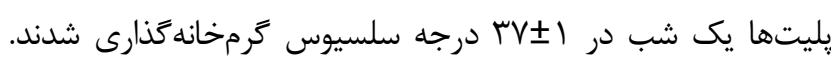

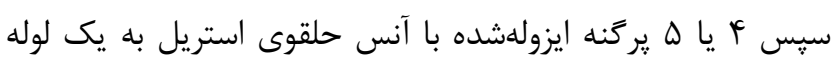

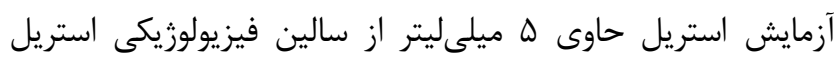

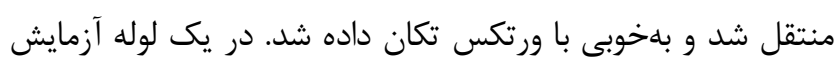

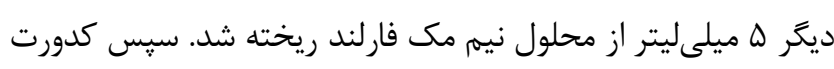

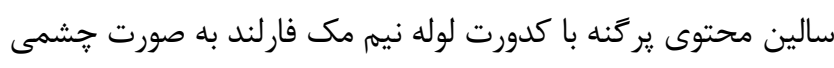

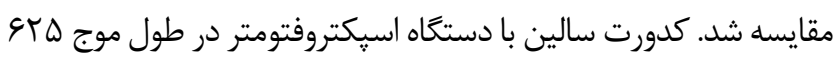

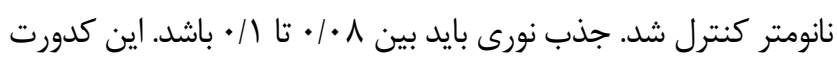

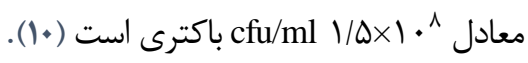




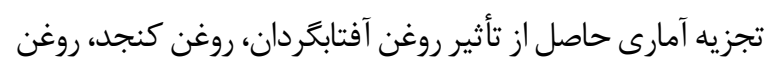

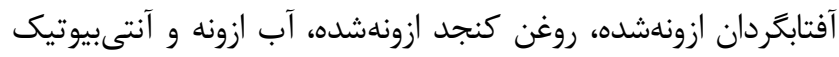
سييروفلوكساسين (CP) به عنوان كنترل مثبت و آب مقطر به عنوان آندان

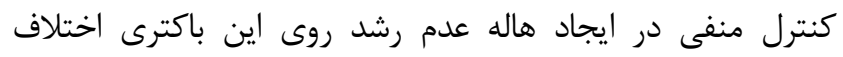
معنى دارى بعد از

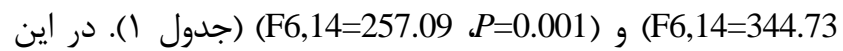
آزمايش فرض همكنى واريانسها محقق شد (Sig=0.514) و و ( (Sig=0.149)، بنابراين دادههاى آزمايش نرمال بودند و آزمايش دقت
تجزيه و تحليل قطر هاله عدم رشد با استفاده از آناليز واريانس

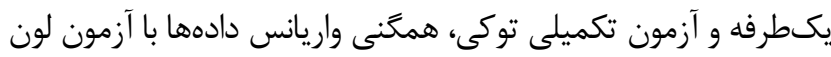

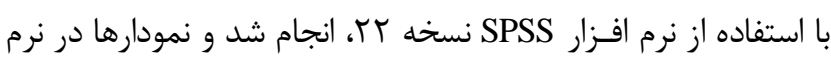

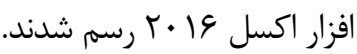

يافته ها و بحث

هاله عدم رشد تيمارها روى باكترى استافيلوكوكوس بـون

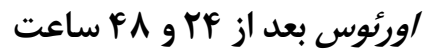
داشت.

جدول 1. مقايسه ميانكين قطر هاله عدم رشد حاصل از تأثير تيمارها روى باكترى/ستافيلوكوكوس/ورئوس بعد از ب و و ب ساعت با آزمون توكى در سطح احتمال

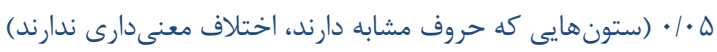

\begin{tabular}{|c|c|c|c|}
\hline \multicolumn{2}{|c|}{ ميانكين قطر هاله عدم رشد (ميلىمتر) } & \multirow{2}{*}{ تركيبات } & \multirow{2}{*}{ رديف } \\
\hline is & rF & & \\
\hline $1 / / V \pm \cdot / \cdot r^{E}$ & $\mid / V I \pm \cdot / \cdot 1^{E}$ & روغن آفتابكردان & 1 \\
\hline $1 / / V \pm \cdot / / 1^{E}$ & $I / V I \pm \cdot / I Y^{E}$ & روغن كنجد & r \\
\hline$F / \cdot \cdot \pm \cdot / \mu^{D}$ & $r / \cdot \cdot \pm \cdot r)^{D}$ & روغن آفتابكردان ازونهشده & $r$ \\
\hline$F / A r \pm \cdot / F Y^{C}$ & $r / \cdot \pm \cdot / r \Lambda^{C}$ & روغن كنجد ازونهشده & r \\
\hline $9 / \cdot \cdot \pm \cdot / \wedge^{B}$ & $\Lambda / \cdot \pm \cdot / \Lambda^{B}$ & 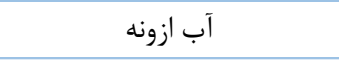 & $\Delta$ \\
\hline $\mid r / A T \pm \cdot / r{ }^{A}$ & $\mid r / \cdot \cdot \pm \cdot / T \Lambda^{\mathrm{A}}$ & آنتى بيوتيك سيبروفلوكساسين & 9 \\
\hline$\cdot \pm \cdot{ }^{\mathrm{E}}$ & $\cdot \pm \cdot{ }^{\mathrm{E}}$ & 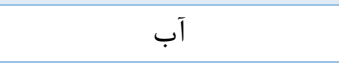 & $\checkmark$ \\
\hline
\end{tabular}

راههاى مختلف ازوندرمانى با موفقيت در برابر عفونتهاى مختلف مانند عفونتهاى داخل خشم و وازينيت مورد استفاده قرار

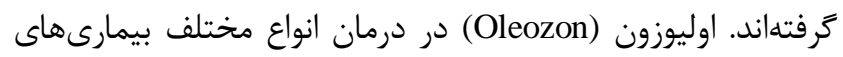

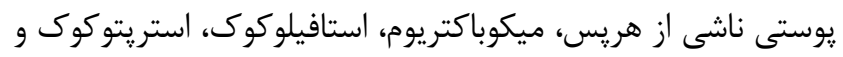

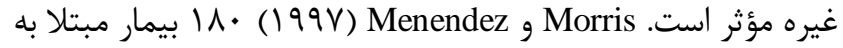
عفونت هريس سيميلكس در لبها را با استفاده از دوزهاى مختلف

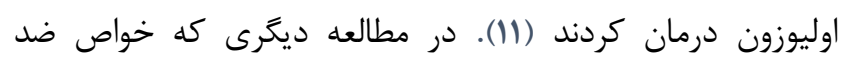

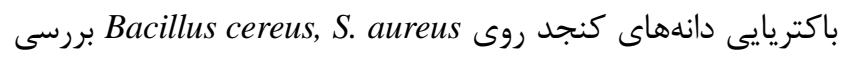

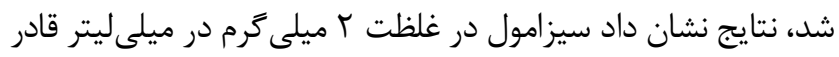

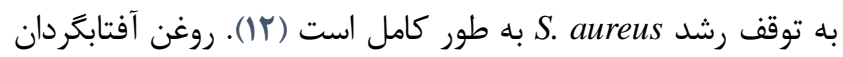

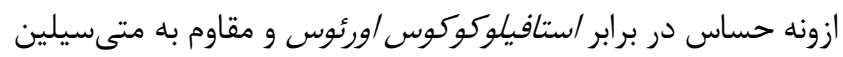

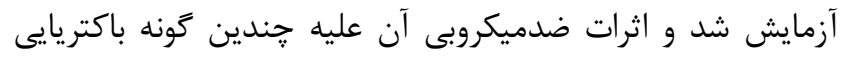

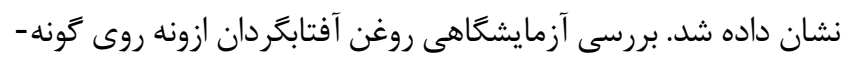

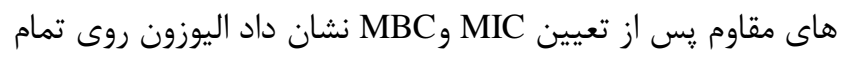

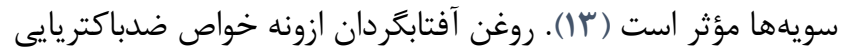

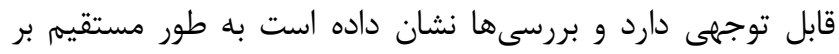

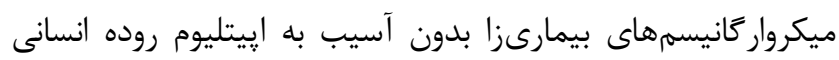

ميانكين دادها به روش مقايسه ميانكين (اج اس دى- توكى -

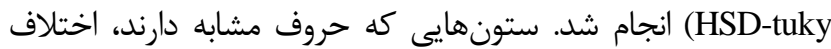

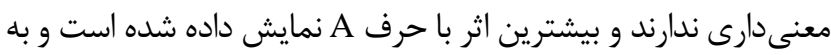
ترتيب كاهش مقادير از حروف ديكر با توجه به اج اس دى دئ توكى حروف كذارى شد)

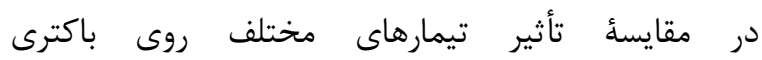

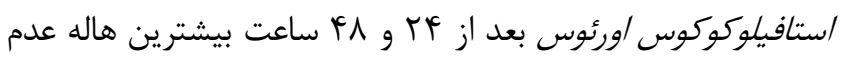

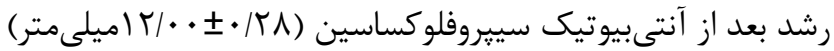

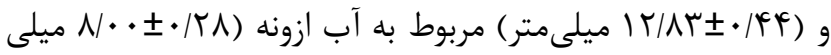
متر) و ( ( خاصيت مهاركنندىى و كشندگى ميكروار كانيسم مربوط به خواص

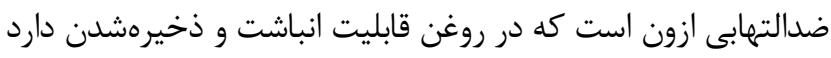
و موجب خواص ضدباكتريايى روغن ازونه مىشود. نتايج حداقل غلظت كشندگى و حداقل غلظت مهارى تيمارهاى مختلف روى رئ

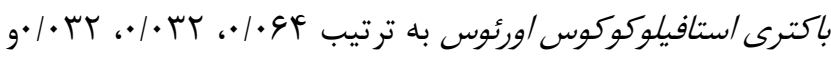

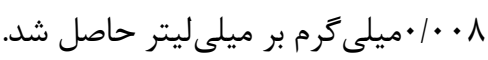




$$
\begin{aligned}
& \text { براى تركيبات شيميايى باشند و در فرمولاسيونهايى نظير يماد، } \\
& \text { لوسيون هاى يوستى و غيره به كار روند. } \\
& \text { سباسگزارى } \\
& \text { اين تحقيق حاصل پايان نامه دانشجويى كارشناسى ارشد با } \\
& \text { كد · · • } \\
& \text { تعار ض منافع } \\
& \text { بين نويسندگان تعارض در منافع گزارش نشده است. }
\end{aligned}
$$

\section{References}

1. Harris L, Foster S, Richards R. An introduction to Staphylococcus aureus, and techniques for identifying and quantifying $\mathrm{S}$. aureus adhesions in relation to adhesion to biomaterials: Review. Eur Cell Mater. 2002; 4(3):100-20. [DOI:10.22203/eCM.v004a04] [PMID]

2. Jawetz E, Melnick JL, Adelberg EA. Medizinische Mikrobiologie. Berlin: Springer-Verlag; 2013.

3. Bowersox J. Experimental staph vaccine broadly protective in animal studies [Internet]. 1999.

4. Wright GD. Something new: Revisiting natural products in antibiotic drug discovery. Can J Microbiol. 2014; 60(3):147-54. [DOI:10.1139/cjm2014-0063] [PMID]

5. Asr-e Emrooz Newspaper. Antibiotic drug control [Internet]. 2016.

6. Sengupta S, Chattopadhyay MK, Grossart HP. The multifaceted roles of antibiotics and antibiotic resistance in nature. Front Microbiol. 2013; 4:47-52. [DOI:10.3389/fmicb.2013.00047] [PMCID]

[PMID]

7. Badouin H, Gouzy J, Grassa CJ, Murat F, Staton SE, Cottret L, et al. The sunflower genome provides insights into oil metabolism, flowering and asterid evolution. Nature. 2017; 546(7656):148-52. [DOI:10.1038/nature22380] [PMID]

8. Sediqi MN. Adaptability of oilseed species at high altitudes of Colorado and technology transfer to Afghanistan [PhD dissertation]. Fort Collins, Colorado: Colorado State University; 2012.

9. Bashi S, Alsuwaidan S, Awada A, Jumah M, Alem A. Diabetic neuropathy: Correlation with other microvascular complications. Neurosciences. 2002; 7: 86-91.
عمل مى كند (IF). در عفونتهاى ناشى از انگلاها و آكنه كاربرد يمادها و روغن ازونه نظير روغن آفتابخردان ازونه با به حداقل رساندن

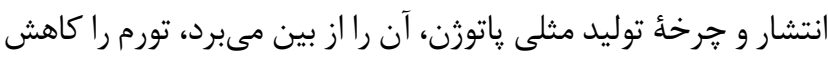

مى مهد و باعث بهبودى سريع مىشود (IF). نتايج تحقيق Bocci)

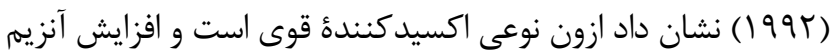
هاى آنتىاكسيدان سلولى را تحريك مى كند و درنهايت منجر به مهار استرس اكسيداتيو مىشود و اين ممكن است در درمان بسيارى از بيمارىها از جمله HIV مؤثر واقع شود (1).

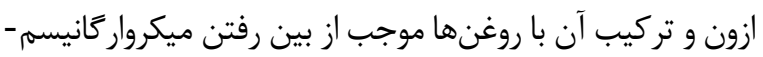

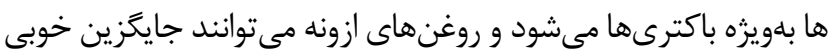

10. Wikler M, Matthew A. Methods for dilution antimicrobial susceptibility tests for bacteria that grow aerobically: Approved standard. CLSI (NCCLS). 2006; 26(2):9-16.

11. Morris G, Menendez S. Oleozon in gynecology. Paper presented at: Second International Symposium on Ozone Applications. 24-26 March 1997; Havana, Cuba.

12. Kumar CM, Singh SA. Bioactive lignans from sesame (Sesamum indicum L.): Evaluation of their antioxidant and antibacterial effects for food applications. Int J Food Sci Tech. 2015; 52 (5):293441. [DOI:10.1007/s13197-014-1334-6] [MID] [PMCID]

13. Lezcano I, Nuñez N, Espino M, Gómez M. Antibacterial activity of ozonized sunflower oil, oleozón, against Staphylococcus aureus and Staphylococcus epidermidis. OS \& E. 2000; 22(2):207-14. [DOI:10.1080/01919510008547221]

14. Menéndez S, Re L, Falcón L, Argote MB, Mendez I, Fernandez D, et al. Safety of topical Oleozon $®$ in the treatment of tinea pedis: Phase IV clinical trial. Int J Ozone Therapy. 2008; 7 (1):55-9.

15. Bocci V. Ozonization of blood for the therapy of viral diseases and immunodeficiency: A hypothesis. Med Hypotheses .1992; 39(1):30-4. [DOI:10.1016/0306-9877(92)90136-Z] 